\title{
A Note on the Early History of the Ross Institute
}

\author{
LISE WILKINSON and DAVID J BRADLEY*
}

In a recent article on Aldo Castellani and the origins of the Ross Institute, ${ }^{1}$ as well as in the above contribution, G C Cook has referred in passing to the project's Organising Secretary, Major H Lockwood Stevens, and in detail to numerous letters exchanged between members of the Organising and Executive Committees which are preserved in the Ross Archives at the London School of Hygiene and Tropical Medicine (LSHTM), and others in the Seamen's Hospital Society archive.

One letter not mentioned in Cook's paper was written by Lockwood Stevens many years later, to his former secretary, Miss Ethne Roberts, who had joined him at the Ross Institute in 1926. She had transferred with him, and it, to the London School of Hygiene and Tropical Medicine in 1934, when after the deaths of both Ross and Sir William Simpson the Ross Institute became part of the School, and eventually its Department of Tropical Hygiene. ${ }^{2}$ It is an extraordinary letter, casting light on the early difficulties of the fledgling Institute and its organization and administration, as experienced by Stevens and Miss Roberts. In view of the contents of the letter, it is of interest that Castellani himself, in his autobiography, ${ }^{3}$ passes briefly but positively over the founding and early years of the Ross Institute, providing no hint of the traumatic reality of the period. Unlike the self-serving Castellani, Simpson, loyal friend and admirer of Ross, genuinely wanted to create an Institute as a lasting monument to his distinguished work. ${ }^{4}$

The letter was at some stage passed to Professor Leonard Bruce-Chwatt who was Director of the Ross Institute following the death of George Macdonald in 1967, until he retired in 1974. Bruce-Chwatt passed the letter in confidence to Bradley, his successor, in 1974. Whether Bruce-Chwatt received it directly from Miss Roberts or by way of Macdonald is not known. As an additional contribution to the story of

* Lise Wilkinson, PhD, The Wellcome Trust Centre for the History of Medicine at UCL, 24 Eversholt Street, London NW1 1AD. Prof. David Bradley, Department of Epidemiology and Population Sciences, Tropical Health Epidemiology Unit, London School of Hygiene and Tropical Medicine, Keppel Street, London WC1E 7HT.

\footnotetext{
${ }^{1}$ G C Cook, 'Aldo Castellani FRCP (1877-1971) and the founding of the Ross Institute and Hospital for Tropical Diseases at Putney', J. med. Biogr., 2000, 8: 198-205.

${ }^{2}$ Miss Ethne Roberts served Lockwood Stevens, and successive directors and members of the Ross Institute's Executive Committee for
}

more than thirty years, finally retiring in 1965 . H Lockwood Stevens had retired in 1948, two years after the death of the Institute's first ViceChairman, Walter Shakspeare. Stevens died in St Thomas's Hospital in July 1964. LSHTM, Annual Reports 1946-47, pp. 14 and 102; 1963-64, pp. 14 and 84; $1964-65$, p. 16.

${ }^{3}$ A Castellani, Microbes, men and monarchs: $a$ doctor's life in many lands, London, Gollancz, 1960.

${ }^{4}$ The story of the turbulent early years of the project and its eventual completion is described in more detail in: L Wilkinson and A Hardy, Prevention and cure, a centenary history of The London School of Hygiene and Tropical Medicine (in press, 2001), see ch. 11, pp. 4-21, 'The Ross Institute'. 


\section{Lise Wilkinson and David J Bradley}

the Institute, representing some of its chequered early history, Dr Cook and the above authors feel that now is the time to publish it in its entirety. This is in the interests of future historians, and as documentation of the gallant struggles of Stevens and of Miss Roberts to keep afloat the Ross Institute, and during the Second World War also the London School of Hygiene and Tropical Medicine, for more than twenty-five years.

The letter was sent from Stevens' home, Knowle, Elm Avenue, East Preston, Sussex, and was dated 23 January 1956. The full text follows:

\section{Dear Miss Roberts}

When I was attending the funeral of Sir Malcolm Watson, I suddenly realised that I was the only surviving member of the Ross Institute who had knowledge of its history from the very beginning and, in fact, could write its history. I have no intentions of doing this, but considering its early days, I can say that it was a miracle that in the short space of ten years, from 1923 to 1933, it rose from nothing to the highly respected institute concerned with malaria control and tropical hygiene in industry it became, with branches overseas. Its name was almost a household word throughout the tropics, so much so that it was incorporated with the London School of Hygiene and Tropical Medicine-to become the Tropical Hygiene Department in the University of London, with a Chair later.

The reason I am writing this short summary is for your personal use, as you are the only surviving member of the original staff still at the Institute. Not only were you my assistant and right hand for 25 years, but you acted as confidential secretary to three great men, Sir Ronald Ross, Sir William Simpson and Sir Malcolm Watson. In addition, you worked very closely with the Chairman, Sir Charles McLeod, and Walter Shakspeare and Mr Forsythe. But for these last three the Ross Institute could never have survived.

Before dealing with the part you played in those vital eight years, 1926/33, I will give you a brief history of the preceding years, 1923/26.

Sometime in 1923, Sir William Simpson and Dr Aldo Castellani launched an appeal for a memorial to Ronald Ross. Although the appeal was "The War Against Malaria", the memorial was for a "Ross Clinic". In other words, the promoters were using Ross's name to fund something of a clinical nature, whereas Ross's work was directed towards preventive work in the field. The appeal was a complete 'flop', for more reasons than one.

In desperation, Sir William Simpson approached an old Calcutta friend of his, Sir Charles McLeod, ${ }^{5}$ and pleaded with him to become Chairman and help them with the proposed memorial to Ross.

This is where I came into the picture. In 1923, McLeod was chairman of a disabled men's charity for which I was doing some voluntary work. Sir Charles sent for me and told me about his interview with Simpson. He said he was only interested in the prevention of malaria in industry in the tropics and asked me to see the so-called Ross Memorial Committee and find out what I could about it. If I thought anything could come of it, he said he would accept the chairmanship, providing I took charge of the appeal work and general organisation, on a part-time basis.

In all my experience I have never attended a meeting like the first of the original Ross Memorial Committee, and also several following ones. Gilbert \& Sullivan could have doubled

\footnotetext{
${ }^{5}$ Sir Charles McLeod (1858-1936). McLeod was not a medical man but a chairman of various tea companies and banks who had gone out to India in 1877 and become a friend of Simpson's
}

during his years as Health Officer in Calcutta in the 1880 s and 1890 s. See Wilkinson and Hardy, op. cit., note 4 above. 


\section{The Early History of the Ross Institute}

their fortunes could they have dramatised those meetings. I would have advised Sir Charles McLeod to have dropped the whole thing then and there, but for one person-Sir William Simpson. I met him several times and found he was a 'field' man at heart and would back any preventive medicine research. As a result of meetings with Simpson, McLeod, Forsythe and Shakspeare, we managed to get the clinic idea dropped, but we had to include a research hospital. That is how the original name became the Ross Institute and Hospital for Tropical Diseases.

In 1923 then, I took on the part-time job of Organising Secretary with my own one assistant, and went on gaily raising money for malaria control in the tropics until 1925 when we had enough money to buy Bath House in Putney, and equip it with two wards and research laboratories.

This is where you come in. It was decided to have the Institute opened by H.R.H The Prince of Wales in July 1926, and he had promised to do this. At that time a friend of Castellani's was acting as Secretary to the Institute, but did little or no work. About a month before the official opening, the Committee found to their horror that the Secretary had taken no steps whatever with regard to the arrangements or invitations. I was called in and asked whether I could possibly arrange everything in a month and take over the whole administration of the Institute. I agreed providing I was given carte blanche.

I immediately engaged two temporary assistants to help me clear up the mess and get the invitations out, etc. You were one of those assistants, and we did succeed-not only in getting everything done in time, but we also received many congratulations.

Your work then was so useful to me that I asked you to stay on permanently to help on the appeal side of my work. Shortly after, there was a vacancy as my senior assistant. You were appointed and took over the accounting -in fact became assistant secretary of the Ross Institute. You were responsible for changing the entire accounts over to the King Edward's Hospital Fund system.

The next crisis came in 1927. I had raised a considerable sum of money for malaria prevention work and this was being frittered away on a small hospital which was virtually a private nursing home for patients of one of the Directors. For some time I had been in contact with Sir Malcolm Watson and knew he was retiring from Malaya in 1928. I told the Committee I would not raise money for malaria control work unless they could get the services of Malcolm Watson to carry out the policy on which my appeal work was based.

In October 1927, I went to Calcutta and engaged Watson as Principal of Malaria Control of the Ross Institute to take up his duties on his retirement in 1928, and this news was cabled round the world from Calcutta. After that I toured India, Burma, Malaya and Ceylon on propaganda work and was away for six months. You carried on at home most successfully during my absence.

The next serious incident was in 1929. Watson and I were being sent to India and Ceylon from October 1928 to April/May 1929. Castellani had an ex-officer patient who was hard-up, and he actually got the Committee to appoint this man as my deputy, on the grounds that it was necessary to have a man in charge while I was away. This person had no qualifications or office experience whatever, yet was allowed to take over the finances of the Institute during my absence. Immediately on my return from Ceylon you got in touch with me as you were suspicious that all was not well. You told me that you had not had access to certain books during my absence and asked me to look into things at once.

I ordered my deputy to hand over all the books and I soon found that a considerable sum had been embezzled during my absence. I gave him three days to find the money, otherwise he would be charged. He gave me the greater part of the amount he had stolen and I urged 


\section{Lise Wilkinson and David J Bradley}

the Committee not to take criminal proceedings, as the scandal would do great harm to the Institute.

But for your prompt action, the consequences could have been very serious, as the cheques had been signed in all innocence by Sir Ronald Ross and Sir William Simpson.

You were officially appointed Assistant Secretary of the Ross Institute in November 1929. Except for the uneconomic hospital, things went very well after this, until the death of Sir Ronald Ross on the $16^{\text {th }}$ September 1932 . Then the balloon went up.

In 1933, an opportunity came for the Institute to join the London School of Hygiene and Tropical Medicine and for the Hospital to be incorporated in the Tropical Diseases Hospital of the Seamen's Hospital Society. Castellani did everything in his power to prevent the amalgamation, but eventually the Ross Institute joined the School on January $1^{\text {st }}, 1934$.

The next crisis was the outbreak of war in 1939, when my office was moved to my house in Ealing. In spite of bombs, etc., we kept things going between us until the next incident in 1940.

The Accountant and acting Secretary of the School was dismissed and I was asked to take over his duties in addition to my own-at a week's notice. As soon as I took over, the accounts clerk left, and you were asked to take over from her. In fact, you and I were responsible for the whole accounting of the School on only a week's notice-probably during the most difficult period of its history.

"Pay-as-you-earn" income tax came into being, with all its extra work. A great deal of additional work was involved in making up and adjusting the pay and salaries of those on active service or seconded to other Government work, and the collection of superannuation payments from scattered staff. All this you did with the help - or hindrance - of only one girl, and sometimes she was only part-time.

During the war, we completely re-organised the accounting and put in a new system. As soon as the war ended we were exceptionally busy preparing post-war estimates, dealing with new salary scales, new and returned staff. In fact, we were both overworked for nearly eight years. The two of us were Secretary, Finance Officer, Accountant and Organising Secretary of the School and the Ross Institute combined. All this, in spite of periods of dusk-to-dawn bombings, V.ls and V.lls, A.R.P and fire-watching duties. Yet at no time was there a breakdown.

We worked hard to maintain the voluntary contributions to the Ross Institute through the war years and had an up-hill fight to gradually win back support from those companies which were over-run by the Japanese occupation in the Far East.

I could, of course, go on for ever, with details of the part you played, but this is enough to show your important influence on the miracle of the Ross Institute.

Yours sincerely

Major H. Lockwood Stevens, O.B.E. 